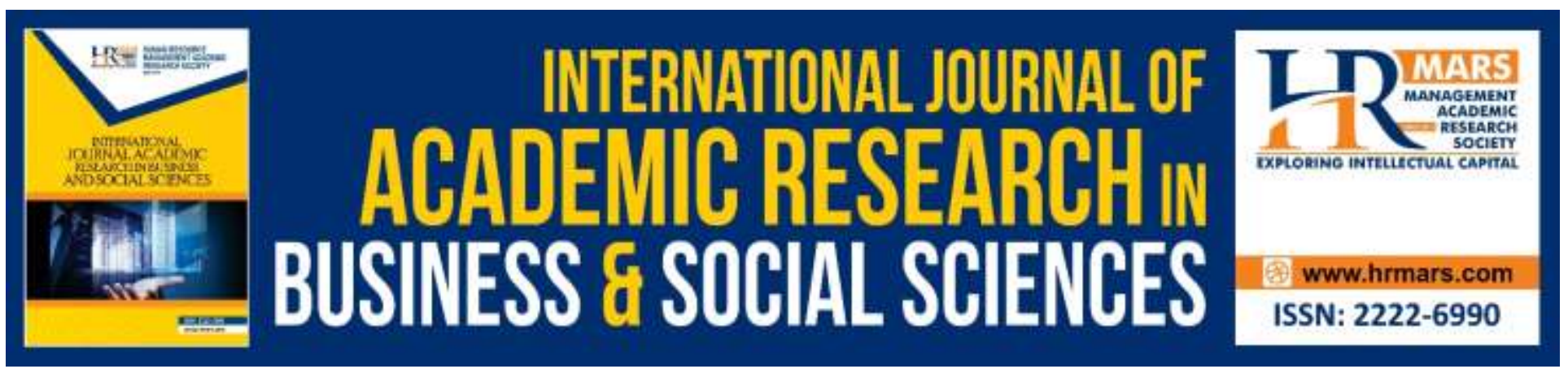

\title{
Crude Palm Oil Price Fluctuation in Malaysia
}

Mohamad Azwan Md Isa, Azlan Taha Baharim, Suhana Mohamed, Mohd Khairul Ariff Noh, Ferri Nasrul, Wan Muhd Faez Wan Ibrahim, Siti Salwa Hassan

To Link this Article: http://dx.doi.org/10.6007/IJARBSS/v10-i5/7319

DOI:10.6007/IJARBSS/v10-i5/7319

Received: 25 March 2020, Revised: 28 April 2020, Accepted: 09 May 2020

Published Online: 29 May 2020

In-Text Citation: (Isa et al., 2020)

To Cite this Article: Isa, M. A. M., Baharim, A. T., Mohamed, S., Noh, M. K. A., Nasrul, F., Ibrahim, W. M. F. W., \& Hassan, S. S. (2020). Crude Palm Oil Price Fluctuation in Malaysia. International Journal of Academic Research in Business and Social Sciences, 10(5), 879-892.

\section{Copyright: (c) 2020 The Author(s)}

Published by Human Resource Management Academic Research Society (www.hrmars.com)

This article is published under the Creative Commons Attribution (CC BY 4.0) license. Anyone may reproduce, distribute, translate and create derivative works of this article (for both commercial and non-commercial purposes), subject to full attribution to the original publication and authors. The full terms of this license may be seen at: http://creativecommons.org/licences/by/4.0/legalcode

Vol. 10, No. 5, 2020, Pg. 879 - 892

http://hrmars.com/index.php/pages/detail/IJARBSS

JOURNAL HOMEPAGE

Full Terms \& Conditions of access and use can be found at http://hrmars.com/index.php/pages/detail/publication-ethics 


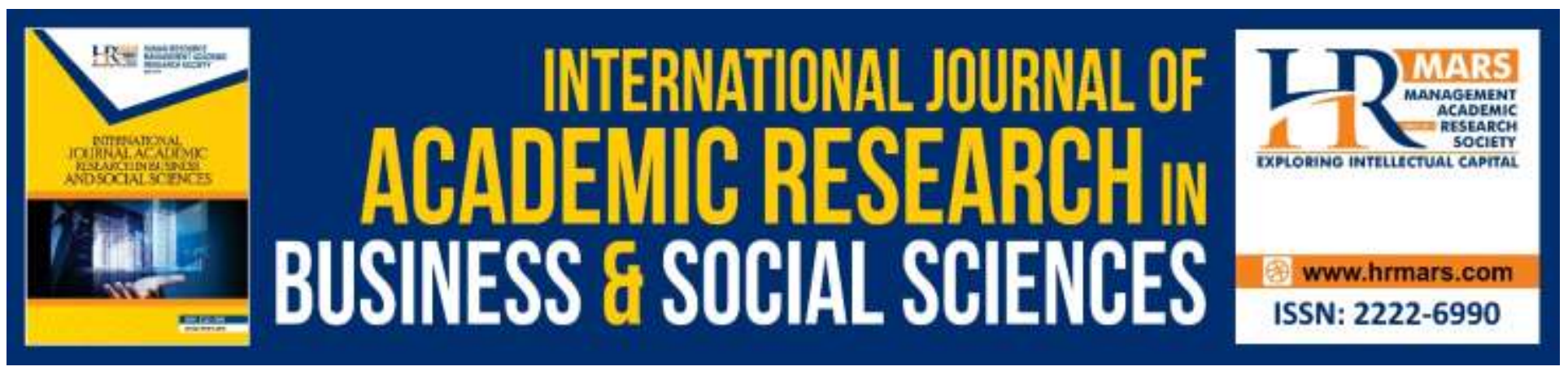

\title{
Crude Palm Oil Price Fluctuation in Malaysia
}

\author{
Mohamad Azwan Md Isa
}

Department of Finance, Faculty of Business and Management, Universiti Teknologi MARA, Johor Branch, Segamat Campus, Malaysia

\section{Azlan Taha Baharim, Suhana Mohamed}

Department of Finance, Faculty of Business and Management, Universiti Teknologi MARA, Johor Branch, Pasir Gudang Campus, Malaysia

Mohd Khairul Ariff Noh, Ferri Nasrul

Department of Finance, Faculty of Business and Management, Universiti Teknologi MARA, Johor Branch, Segamat Campus, Malaysia

\section{Wan Muhd Faez Wan Ibrahim, Siti Salwa Hassan}

Department of Finance, Faculty of Business and Management, Universiti Teknologi MARA, Sarawak Branch, Malaysia

\begin{abstract}
Crude palm oil (CPO) is one of the commodity that contributes aggressively to the Malaysian economy. Malaysia, at present, grasps the position as the world's second-largest palm oil producer and exporter in the world after Indonesia. However, there is uncertainty in the price of CPO, and the trend shows an intense fluctuation for the last 20 years. The drive of this study is to examine the relationship and the impacts of four macroeconomic variables, namely the exchange rate (EXC), inflation (INF), money supply (M3) and gross domestic product (GDP) on the Malaysian CPO price. The focus is on the macroeconomic factors that affect CPO price in Malaysia from 1999 to 2018. The research uses secondary data collected from the World Bank and Datastream. The study employs descriptive statistics, Augmented Dickey-Fuller test (ADF) unit root, correlation and multiple regression tests to analyze the data. Based on the ADF test results, the data series are integrated or stationary. Pearson's correlation test reveals that the EXC has negative correlation while INF, M3 and GDP indicate a positive correlation with the CPO price, respectively. The multiple regression test results are also consistent with the correlation test. INF and GDP found to be significant variables, whereas EXC and M3 are not. These findings are beneficial to the policymakers, palm oil growers or producers and palm oil-related products manufacturers in their planning, forecasting, and making the best policy-related, business and investment decisions in the future. Through this research, the
\end{abstract}


INTERNATIONAL JOURNAL OF ACADEMIC RESEARCH IN BUSINESS AND SOCIAL SCIENCES

Vol. 10 , No. 5, May, 2020, E-ISSN: $2222-6990$ ㄷ 2020 HRMARS

researcher can conclude the findings and correlation between the macroeconomic factors with CPO price in Malaysia.

Keywords: Macroeconomic, Crude Palm Oil, Factors, Determinants, CPO Price.

\section{Introduction}

Malaysia is the Southeast Asian country comprising of the Peninsular Malaysia and the Malaysian Borneo. The total land area of 330,803 km2 and a population of 32,049,700 based on the 2017 estimate. Malaysia experiences equatorial climate influenced by alternating Northeast and Southwest monsoons bringing rainfall and dry weather, respectively (Tang, 2018).

Oil palms are highly productive and significantly contributed to the Malaysian economy. The development of oil palm plantations benefited rural areas and gave rise to the issues of welfare, human right, equity and demographic change by improving the community incomes (Tang and Al Qahtani, 2019). The biodiversity and environmental management, sustainability certification, increased social corporate responsibility and review of employment policy are among the perceived benefits for the oil palm industry.

Malaysia ranked second in the export of oil palm worth USD 9.7 billion in 2017. The production of palm oil in Malaysia also ranked second in the same year, totalling 21 million metric tonnes. In 2016, the agricultural sector contributed 8.1 per cent of the total Malaysian Gross Domestic Product (GDP), equivalent to RM89.5 million, and the oil palm sector alone constituted $43.1 \%$ of the GDP (Department of Statistics, 2017).

In Peninsular Malaysia, Johor has the largest area of land $(745,630$ ha) planted with oil palms followed closely by Pahang (732,052 ha). Private plantations owned 61.2 per cent of the total oil palm planted area in 2016, while the rest shared by federal and state government agencies and independent smallholders (Malaysian Palm Oil Board, 2017).

The palm oil industry understood as an essential sector that contributes a lot to the Malaysian Gross National Income (GNI). In 1990, the Malaysian Palm Oil Council (MPOC) established to promote its products and the market expansion by enhancing the image of palm oil and creating better acceptance of palm oil using new technologies and economic advantages and environmental sustainability. Then, in 1998, the MPOC was rebranded as Malaysian Palm Oil Board (MPOB) to promote and develop objectives, policies and priorities for the well-being of the Malaysian palm oil industry.

According to Norlin et al. (2018), the Malaysian palm oil industry not only plays an essential role in economic development but also enhances the country's socio-economic level. It was evidenced by the contributions of Malaysian palm oil sector as the fourth most significant contributor to Malaysia's GNI. As the price can be one of the factors that influence the level of income, namely GNI, then it is very crucial to understand what determines the price. In the case of the palm oil industry and referred as the price of CPO. 
INTERNATIONAL JOURNAL OF ACADEMIC RESEARCH IN BUSINESS AND SOCIAL SCIENCES

Vol. 10, No. 5, May, 2020, E-ISSN: $2222-6990$ @ 2020 HRMARS

According to Chuangchid et al. (2012), many determinants are influencing the CPO price. One of them is the availability of substitutes, such as the prices of soybean oil or kernel oil because they have a similar application in the food industry. A higher price could also lead to more capital needed to invest and the need to recruit more labours in order to increase the production volume for palm oil.

Thus, this study aims to investigate how macroeconomic factors affect the CPO price in Malaysia. Based on the expectation of understanding the determinants of CPO price and the ultimate objective to help the government to increase the $\mathrm{GNI}$, this study looks at this matter from the perspective of the macroeconomic factors.

\section{Research Background}

According to Mukhriz and Applanaidu (2017), Malaysia and Indonesia being the top two producers, contribute 85 per cent of the world's palm oil export and around 5 per cent of Gross Domestic Product (GDP), respectively. Malaysia per se has consumed 3.7 million metric tons of palm oil in 2019, which amounted to RM38 billion of GDP that is equivalent to 2.8 per cent of total Malaysia's GDP. Therefore, the need for studying the impacts on CPO price is crucial to the growth of our economy.

Research also has found that the CPO is one of the leading commodity traded worldwide. Palm oil is considered as the second largest comestible oil and accounts for approximately 23 per cent of the world's fats and oil supply. The previous study has linked the effect of CPO prices on currency exchange. It may have different impacts on oil-exporting countries and oil-importing countries in terms of currency exchange rates.

An increase in money supply indicates an increase in demand for money circulation, thus represents an active economic activity. In this research, we attempt to associate the relationship between money supply and CPO price. In Malaysia, the money supply categorized into M1, M2 and M3. M1 is the currency in circulation and demand deposits of the private sector. $M 2$, on the other hand, is the combination of $\mathrm{M} 1$ and quasi money that is short term time deposits and specific money market instruments. Meanwhile, M3 includes $\mathrm{M} 2$ in addition to long term deposits. In this study, we use M3, namely broad money, to examine the relationship between money supply and CPO price in Malaysia.

In the recent decade, our economy faces many uncertainties such as recession and rising inflation that emerged as the main risk affecting the macroeconomic outlook of developing Asia. Inflation, which measures the general price trends in the economy, is often related to purchasing power in one economy with oil as a significant material in production activities used in many ways, such as transportation. Therefore an increase in oil price may lead to an increase in the cost of end products. So is the impact on the production cost if there is an uprising in the CPO price.

Producers of palm oil must manage their resources efficiently in order to generate sufficient amount to export or use domestically, and the government of Malaysia needs to look into all the macroeconomic variables that may affect the palm oil industry. We need to understand the relationship and impact between the variables with the CPO, either it is positive or negative or no impact at all to the palm oil industry. Therefore, this research needs a clear framework to come up with a sound conclusion on the matter. 
INTERNATIONAL JOURNAL OF ACADEMIC RESEARCH IN BUSINESS AND SOCIAL SCIENCES

Vol. 10, No. 5, May, 2020, E-ISSN: 2222-6990 @ 2020 HRMARS

\section{Literature Review}

This section reviews the previous researches related to the topic. Based on the discussion, many macroeconomic variables lead to a change in CPO price. Several related articles reviewed to support the study.

\section{Crude Palm Oil Price}

Based on a study conducted by Zabid and Abidin (2015) on the world's oil and fats market, palm oil is one of the critical agricultural commodities with Malaysia and Indonesia become the top list countries in the palm oil-producing. Still, the price of palm oil retains changing all over time. Therefore, the accuracy of forecasting CPO price is an essential understanding for the investors and government agencies that deal with the associated risks and uncertainties (Arasim \& Karia, 2015).

Based on the statistics, the demand for palm oil has been increasing worldwide (Bentivoglio, Finco \& Bucci, 2018). The multi-purpose in use, combined with a market price, make palm oil an attractive product. According to Rahman (2013), palm oil is currently the second most important vegetable oil in the world oils and fats market, accounting for 14.35 per cent of world production of seventeen major oils and facts.

\section{Exchange Rate}

The rate at which one currency traded for another currency is called the exchange rate. It viewed as the estimation of one nation's currency in connection to another currency. Earlier studies have shown that the exchange rate is a macroeconomic fundamental to determine crude palm oil. In this study, the exchange rate becomes one of the independent variables as a determinant of CPO in Malaysia.

Additionally, Aziz and Applanaidu (2017) examined the impact of palm oil prices on exchange rates in Malaysia and Indonesia with monthly time series data from 1983 to 2015 using Dynamic Ordinary Least Squares (DOLS) method. They found a positive relationship between CPO and exchange rate, which means that the determinant of CPO on the exchange rate is significant. Rifin (2010) also found a positive relationship between $\mathrm{CPO}$ and exchange rate. He said that the depreciation in the rupiah would make CPO from Indonesia cheaper, which creates more incentive for producers to export their CPO.

Besides, Adeyemo (2015) investigated the determinants of palm oil in Nigeria between 1971 and 2010 by using Augmented-Dickey Fuller unit root test, co-integration and error correction specification. He found a significant relationship in the long run, and short-run, respectively and the exchange rate has a positive relationship with CPO in Nigeria. He also stated that the elasticity values of the exchange rate in both the short and long run suggest that devaluation will decrease the import of palm oil products, thereby encouraging local production which will subsequently raise palm oil production.

Meanwhile, Ahmadian (2015) found a negative relationship between exchange rate and crude oil price in his study to investigate the influence of oil price fluctuations on the nominal exchange rate of U.S. dollar in Libya from January 2000 to December 2015 using Vector Error Correction Estimates (VECM). 


\section{Inflation}

An increase in oil price generally will increase goods and services prices. The petrol and diesel prices increment also affected many people directly. As a result, inflation rises, and it showed a wrong indication for the economy (Shariff et al., 2006). Soundarapandiyan and Ganesh (2017) investigated the linkage between differential change rate of crude oil prices and inflation in India for the period from 2001 to 2015 using regression, collinearity and intercorrelation plus an antagonistic relationship between crude oil price and inflation. There is a clear indication that whenever inflation increases, there is a decrease in crude oil price and vice versa.

Meanwhile, Punati and Raju (2017) examined the significant determinants of crude oil prices in India with once-a-month time-series data from April 1994 to December 2015 using Ordinary Least Square (OLS) method. They revealed that inflation and crude oil price have a positive relationship and concluded that the determinants of crude oil prices, namely inflation, found to be significant.

Ahmed (2018) examined the relationship between the crude oil price fluctuations and inflation behaviour in Oman from 1990 to 2017 using Auto-Regressive Distributed Lag (ARDL) approach. He found that there is the existence of a long-run relationship between these variables and that the crude oil price fluctuations have a direct impact on the inflation rate in Oman.

\section{Money Supply}

Mahdi (2012) conducted the study to investigate whether there is a long-run relationship between the concerned variables in Oman during the period 1990 to 2016 using Autoregressive Distributed Lag (ARDL) and found a positive relationship between money supply and crude oil prices. Rahman (2013) stated that the concentration of the study on crude oil price and money supply is encouraged by their association with the macroeconomy and the stock markets. Understanding of this link is of pronounced significance for financial hedgers, portfolio managers, asset allocators and financial analysts. It is also significant for the formulation of the U.S. monetary policy.

Meanwhile, Cheng, Shi, Yu, and Zhang (2019) examined how the Chinese macroeconomy reacts to uncertainty shocks in international crude oil markets by using Structural Vector Autoregressive (SVAR). They found that there is a negative relationship between crude oil price and money supply and indicated that one-quarter-lagged oil prices and uncertainty have significant negative impacts on the money supply. The negative sign suggests that the Chinese government increases the money supply when the first and second-moment fluctuations in oil prices decline. In other words, it implements an expansionary monetary policy in reaction to a drop in the fluctuation of oil prices.

\section{Gross Domestic Product}

Susila (2004) conducted the study to deliberate the contribution of palm oil to economic development, poverty alleviation and income distribution in Indonesia. She found a significant relationship between CPO and GDP. It means that when CPO increases or decreases, the GDP does the same. 
INTERNATIONAL JOURNAL OF ACADEMIC RESEARCH IN BUSINESS AND SOCIAL SCIENCES

Vol. 10, No. 5, May, 2020, E-ISSN: 2222-6990 @ 2020 HRMARS

Applanaidu, Arshad, Shamsudin, and Hameed, (2011) studied to appraise and investigate the relationship between biodiesel demand and the Malaysian palm oil market and also found a positive relationship between GDP and CPO.

However, according to Zakaria et al. (2017) who conducted the study to identify the factors that influence the demand for palm oil in India by using Autoregressive Distributed Lag (ARDL) models from 1980- 2015, have found a significant negative relationship between CPO and GDP. The negative relationship between GDP and palm oil demand shows that Indians accept palm oil as an inferior good.

\section{Theoretical Framework}

The macroeconomic factors that were mainly focused by previous researchers to identify the relationship and impact on CPO such as exchange rate, inflation, money supply, gross domestic product and soybean oil (Aziz \& Applanaidu, 2017; Zakaria et al., 2017). Hence, the theoretical Framework for this current study is as in the following figure.

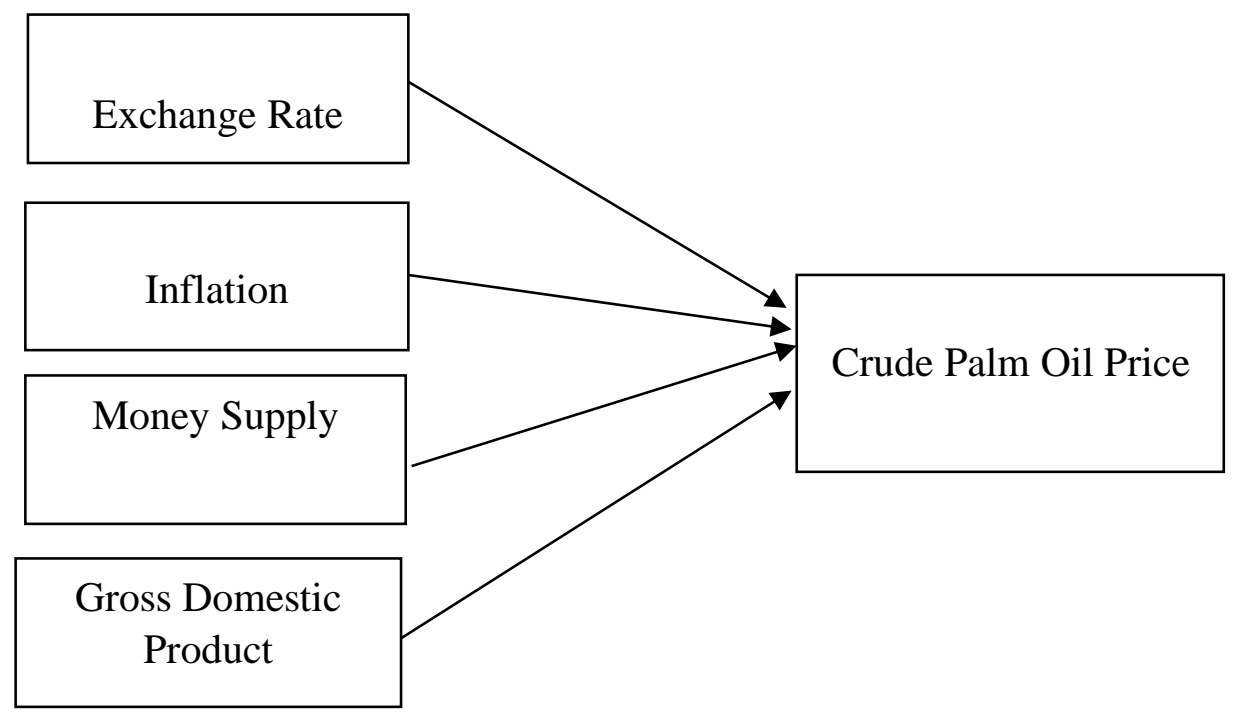

\section{Independent Variables}

\section{Dependent Variable}

Figure 1. Theoretical Framework for the study (Aziz \& Applanaidu, 2017; Zakaria et al., 2017).

The figure shows that there are four (4) independent variables, namely exchange rate, inflation, money supply and gross domestic product (GDP) and Crude palm oil (CPO) price is the dependent variable.

\section{Research Methodology Research Design}

This study is constructed based on secondary data collected from two sources which are the World Bank and Data Stream. The paper aims to examine the relationship between the dependent variable, CPO price and independent variables, Exchange rate, Inflation, Money Supply and Gross Domestic 
INTERNATIONAL JOURNAL OF ACADEMIC RESEARCH IN BUSINESS AND SOCIAL SCIENCES

Vol. 10 , No. 5, May, 2020, E-ISSN: $2222-6990$ ㄷ 2020 HRMARS

Product (GDP). All the four variables can become the determinants of CPO price in Malaysia. The annual data extracted are time-series data from 1999 to 2018.

The CPO price measured in Malaysian Ringgit per metric ton (R.M./ton). The exchange rate measured by R.M. per USD, and the inflation rate is measured by the consumer price index (CPI) with the based $2010=100$, and the money supply measured by broad money (M3). Meanwhile, the GDP measured by GDP per capita (constant, 2010 USD).

The study employed the following hypothesis:

$\mathrm{H}_{0}$ : There is no significant relationship between independent variables (exchange rate, inflation, money supply and gross domestic product) and CPO price in Malaysia.

$\mathrm{H}_{1}$ : There is a significant relationship between independent variables (exchange rate, inflation, money supply and gross domestic product) and CPO price in Malaysia.

\section{Research Analysis}

Data analysis is a descriptive analysis that shows a statistical summary of data set for the dependent and independent variables. It measures the mean, median, maximum, minimum, standard deviation, skewness and kurtosis of the data series.

The Augmented Dickey-Fuller (ADF) test used for the unit root or stationary test due to the extensive and complicated set of time series models. The test for stationary is the p-value of the ADF statistic. If the $p$-value is below than 5 per cent significance level, then the null hypothesis is rejected and concluded that the data variable is stationary or has no unit root problem.

Besides, the Pearson's correlation test is employed to determine the correlation between the dependent and independent variables. Then, the multiple linear regression analysis used to determine the relationship, namely significant or insignificant and impact either positive or negative between the dependent variable and independent variables. The equation of the model is as follows:

$$
C P O=\alpha+\beta_{1} E X C+\beta_{2} I N F+\beta_{3} M 3+\beta_{4} G D P+e
$$


INTERNATIONAL JOURNAL OF ACADEMIC RESEARCH IN BUSINESS AND SOCIAL SCIENCES Vol. 10 , No. 5, May, 2020, E-ISSN: $2222-6990$ ㄷ 2020 HRMARS

\section{Findings and Discussion \\ Descriptive Analysis}

Table 1. Results of Descriptive Statistics

\begin{tabular}{|l|c|c|c|c|c|}
\hline & CPO & EXC & INF & M3 & GDP \\
\hline Mean & 2318.083 & 3.67330 & 2.03626 & 2.11728 & 3.94620 \\
\hline Median & 2302.405 & 3.78900 & 1.99174 & 2.12029 & 3.94084 \\
\hline Maximum & 3842.900 & 4.45700 & 3.00000 & 2.14641 & 4.08312 \\
\hline Minimum & 1007.000 & 3.05400 & 1.89928 & 2.07769 & 3.81876 \\
\hline Std. Dev. & 794.316 & 0.38926 & 0.23463 & 0.01944 & 0.08084 \\
\hline Skewness & 0.24220 & 0.20451 & 3.68954 & -0.31132 & 0.10559 \\
\hline Kurtosis & 2.15304 & 2.31383 & 15.7946 & 2.17535 & 1.87783 \\
\hline Jarque-Bera & 0.79332 & 0.53176 & 181.794 & 0.88977 & 1.08654 \\
\hline Probability & 0.67256 & 0.76652 & 0.0000 & 0.64089 & 0.58084 \\
\hline Sum & 46361.65 & 73.4660 & 40.7253 & 42.3456 & 78.9240 \\
\hline Sum Sq. Dev. & 1198783 & 2.87900 & 1.04604 & 0.00718 & 0.12418 \\
\hline
\end{tabular}

Table 1 shows the results of the descriptive statistics. From the table, we could see that the average price of CPO for the 20 years is RM2,318 per metric ton. The lowest price reported is RM1,007 (in 2001) while the highest price is RM3,843 (in 2008). The prices disperse approximately RM794 around or from the mean. The data of CPO price slightly skewed to the right with a flatted-curve.

Meanwhile, for the independent variables during the 20 years, the average exchange rate of R.M. to USD (RM/USD) is RM3.6733, average inflation is around 2.04 per cent, and GDP is approximately 3.95 per cent. The highest exchange rate of RM/USD is RM3.054 while the lowest is RM4.457, the highest inflation is 3 per cent, and the lowest is 1.9 per cent, and the highest GDP is 4.08 per cent with the lowest is at 3.82 per cent.

Whereas, the average money supply, minimum and maximum are just around 2.08 to 2.15 per cent, respectively. The exchange rate shows the most considerable dispersion or volatility through the standard deviation and followed by inflation and GDP. The data series of the exchange rate, inflation and GDP are skewed to the right, where inflation is the most skewed while the money supply slightly skewed to the left. The inflation indicates a high-peaked curve while the exchange rate, money supply and GDP show a flatted-curve, respectively. The other statistics summarized in the table above. 
INTERNATIONAL JOURNAL OF ACADEMIC RESEARCH IN BUSINESS AND SOCIAL SCIENCES Vol. 10 , No. 5, May, 2020, E-ISSN: $2222-6990$ ㄷ 2020 HRMARS

\section{Unit Root Analysis}

Table 2. Results of Unit Root Test

\begin{tabular}{|l|c|c|c|c|}
\hline \multirow{2}{*}{ Variable } & \multicolumn{2}{|c|}{ Level } & \multicolumn{2}{c|}{$1^{\text {st }}$ Different } \\
\cline { 2 - 5 } CPO & No Trend & Trend & No Trend & Trend \\
\hline EXC & -2.3706 & -3.0743 & -5.9915 & -6.1495 \\
& $(0.1623)$ & $(0.1398)$ & $(0.0002)^{*}$ & $(0.0007)^{*}$ \\
\hline INF & -1.1310 & -1.1571 & -3.2154 & -4.4426 \\
& $(0.6808)$ & $(0.8905)$ & $(0.0358)^{*}$ & $(0.0148)^{*}$ \\
\hline M3 & -3.9964 & -4.2156 & -6.9493 & -6.7404 \\
& $(0.0071)^{*}$ & $(0.0183)^{*}$ & $(0.0000)^{*}$ & $(0.0002)^{*}$ \\
\hline GDP & -3.4704 & -3.3813 & -7.4575 & -7.5430 \\
& $(0.0210)^{*}$ & $(0.0838)$ & $(0.0000)^{*}$ & $(0.0001)^{*}$ \\
\hline & 0.1544 & -2.7247 & -5.6913 & -5.8776 \\
& $(0.9615)$ & $(0.2385)$ & $(0.0002)^{*}$ & $(0.0009)^{*}$ \\
\hline
\end{tabular}

* Indicates that the variables are stationary at 5 per cent significance level

In this study, we employ Augmented-Dickey Fuller (ADF) to test the unit root. Table 2 shows the results from the ADF unit root test for each variable at the trend and no trend. Based on the results, only inflation is found to be stationary or has no unit root at both trend and no trend at level order, while the other variables are not stationary or have unit root problem at level order. However, when we convert the data into the first difference, then only we found that all the variables are stationary or integrated at the same order, namely at the first difference. We determine the results based on the probability $(p)$ values that are less than the 5 per cent significance level.

\section{Correlation Analysis}

Table 3: Results of Pearson's Correlation Test

\begin{tabular}{|c|c|c|c|c|c|}
\hline $\begin{array}{l}\text { Correlation } \\
\text { Probability }\end{array}$ & СРО & EXC & INF & M3 & GDP \\
\hline CPO & 1.0000 & & & & \\
\hline EXC & $\begin{array}{c}-0.2209 \\
0.3492\end{array}$ & $\begin{array}{c}1.0000 \\
-----\end{array}$ & & & \\
\hline INF & $\begin{array}{l}0.6052 \\
0.0047 \\
\end{array}$ & $\begin{array}{c}-0.2798 \\
0.2321 \\
\end{array}$ & $\begin{array}{c}1.0000 \\
----- \\
\end{array}$ & & \\
\hline M3 & $\begin{array}{l}0.1627 \\
0.4930 \\
\end{array}$ & $\begin{array}{c}-0.2462 \\
0.2954 \\
\end{array}$ & $\begin{array}{c}-0.0384 \\
0.8722 \\
\end{array}$ & $\begin{array}{c}1.0000 \\
----- \\
\end{array}$ & \\
\hline GDP & $\begin{array}{l}0.6586 \\
0.0016\end{array}$ & $\begin{array}{l}0.1759 \\
0.4581\end{array}$ & $\begin{array}{l}0.2819 \\
0.2285\end{array}$ & $\begin{array}{l}-0.0032 \\
0.9893\end{array}$ & $\begin{array}{c}1.0000 \\
----\end{array}$ \\
\hline
\end{tabular}

Table 3 presents the correlation between the CPO price and the four macroeconomic variables. The results reveal that the exchange rate has a negative but weak correlation with the CPO price. The result means that when the Malaysian currency appreciates against the U.S. dollar, the price of CPO decreases, but when the Ringgit depreciates, it will cause the CPO price to rise. 
INTERNATIONAL JOURNAL OF ACADEMIC RESEARCH IN BUSINESS AND SOCIAL SCIENCES Vol. 10, No. 5, May, 2020, E-ISSN: 2222-6990 @ 2020 HRMARS

Meanwhile, the other three variables, namely inflation, money supply and GDP indicate positive correlations with CPO price, where GDP has the strongest correlation and followed by inflation, whereas money supply just poses weak correlation. These findings suggest that when the country's economy grows, prices of general products and services rise, and more money is injected or circulated into the economy by the government, then the CPO price will follow suit to increase as well.

\section{Multiple Regression Analysis}

Table 4. Results of Multiple Regression

\begin{tabular}{lrrrr}
\hline \hline Variable & Coefficient & Std. Error & t-Statistic & Probability \\
\hline \hline C & -33281.32 & 14249.40 & -2.335629 & 0.0338 \\
EXC & -362.9859 & 335.0302 & -1.083442 & 0.2957 \\
INF & 1346.454 & 552.6564 & 2.436330 & 0.0278 \\
M3 & 5560.000 & 6193.625 & 0.897697 & 0.3835 \\
GDP & 5681.140 & 1555.232 & 3.652920 & 0.0024 \\
\hline \hline & & & & \\
R-squared & 0.683021 & Mean dependent var & 2318.083 \\
Adjusted R-squared & 0.598493 & S.D. dependent var & 794.3164 \\
S.E. of regression & 503.3152 & Akaike info criterion & 15.49263 \\
Sum squared resid & 3799893. & Schwarz criterion & 15.74156 \\
Log-likelihood & -149.9263 & Hannan-Quinn criteria. & 15.54122 \\
F-statistic & 8.080430 & Durbin-Watson stat. & 2.214420 \\
Prob(F-statistic) & 0.001108 & & & \\
\hline \hline
\end{tabular}

Table 4 summarizes the results of a multiple regression test and the econometric model or equation is as shown below.

$$
\mathrm{CPO}=-33281.32-362.9859 \mathrm{EXC}+1346.454 \mathrm{INF}+5560.000 \mathrm{M} 3+5681.140 \mathrm{GDP}
$$

From the results, based on the 5 per cent significance level, we found that inflation (INF) and GDP are significant macroeconomic variables that influence the CPO price in Malaysia. Also, both INF and GDP affect the CPO price positively, where the GDP poses the most significant impact. Whereas, the $p$ values prove that exchange rate and money supply are not significant variables towards CPO price in Malaysia.

Despite the insignificance, the exchange rate might influence the CPO price negatively while the money supply might influence positively. Hence, the impacts of both macroeconomic variables on the CPO price must be as well taken heed by the relevant parties in making any forecasts or decisions.

The R-squared value is quite favourable at 68.3 per cent, and even after the adjustment, the value is still around 60 per cent. The value interpreted as the four macroeconomic variables can explain 60 per cent or more of the variation or fluctuation in the CPO price. The remaining 40 per cent explained 
INTERNATIONAL JOURNAL OF ACADEMIC RESEARCH IN BUSINESS AND SOCIAL SCIENCES

Vol. 10 , No. 5, May, 2020, E-ISSN: $2222-6990$ ㄷ 2020 HRMARS

by other variables not tested in this study. Hence, we recommend those untested variables as the variables for future research.

Lastly, the variables selected just fit in the model for this study as the probability of F-statistic is 0.0011 , which is less than 5 per cent level of significance. Also, the Durbin-Watson statistic of 2.2 confirms that there is no autocorrelation in the residuals of the sample.

\section{Conclusion}

This study mainly aims to investigate the relationship and impacts of four macroeconomic variables, namely EXC, INF, M3 and GDP, with the CPO price in Malaysia from 1999 to 2018. The data found to be integrated but not stationary. However, but when converted into the first difference based on the results revealed by the ADF test.

Pearson's correlation test proved that the CPO price is correlated negatively with the EXC. Despite the weak correlation between the two, interpreted that when the Malaysian currency (R.M.) is strengthening against the USD, the CPO price in Malaysia is going downward or vice versa. This correlation makes sense since Malaysia is the second-largest exporter of the CPO in the world. The export transaction mainly is conducted in the USD. When the R.M. appreciates against USD, the cost to import CPO by importing countries will rise. So, this will affect the total demand for CPO in the world market. In other words, the importing countries will limit or cut down their demand for CPO. As a result of declining demand, the CPO price will fall.

Meanwhile, the CPO price has a positive correlation with the INF, M3 and GDP, respectively. Inflation will affect the level price of goods and services generally, which means the higher inflation, the higher price of goods and services or vice versa. As the main commodity in Malaysia, CPO price will also be affected or increasing due to rising inflation. The money supply also shows the same correlation, where more money circulated in the economy means more demand for products in the market. So is the demand for CPO. Consequently, the CPO price will rise accordingly.

Then, the GDP indicates similar correlation where the higher GDP will contribute towards the rising price of CPO. Higher GDP means the economic activities of the country is prospering. The result explains that more products are produced mainly in this case, palm oil-based products. It is translated into higher demand for CPO and rise in its price.

From the results of multiple regression, INF and GDP found to be significant macroeconomic variables, whereas EXC and M3 are not. In terms of relationship with and impacts on the CPO price, we found similar results for the multiple regression test as reveal by the correlation test, namely EXC (negative impact) and INF, M3 and GDP (positive impacts). These current study findings are consistent with or in support of Shariff et al. (2006) and Susila (2004).

As a recommendation, we urge the government agencies or policymakers to be more proactive in tackling the fluctuation of CPO price. The Central Bank of Malaysia (BNM) must ensure effective and sustainable policies on Malaysian currency exchange and money supply in the economy. The National Economic Action Council (MTEN) must continuously endeavour with strategic and affirmative actions 
INTERNATIONAL JOURNAL OF ACADEMIC RESEARCH IN BUSINESS AND SOCIAL SCIENCES

Vol. 10, No. 5, May, 2020, E-ISSN: 2222-6990 @ 2020 HRMARS

to stimulate economic activities of the country and ultimately boosting the GDP growth. The agencies under the Ministry of Domestic Trade and Consumer Affairs (KPDNHEP) must be strict in law enforcement to curb any profiteering activities in order to avoid inflation from rising.

Lastly, the Malaysian Palm Oil Board (MPOB) should be more aggressive in promoting and developing the palm oil industry in Malaysia by having strategic alliances with the related industries to come up with more palm oil based-products introduced into the market. Conclusively, it is utmost necessary for the CPO price to remain stable in any economic circumstances so that it will not severely affect our economy and national income. The government might also need to look into the related agricultural policy to enhance further the production and quality of CPO using the latest technology.

AcknowledgementThanks to all authors for the time, cooperation and commitment in completion and reviewing of the research paper.

\section{Corresponding Author}

Mohamad Azwan Md Isa.

Department of Finance, Faculty of Business and Management, Universiti Teknologi MARA, Johor Branch, Segamat Campus, Jalan Universiti, 85009 Segamat, Johor, Malaysia.

Email: moham821@uitm.edu.my.

\section{References}

Adeyemo, A. O. (2015). Analyses of the Determinants of Palm Oil Production in Nigeria (1971-2010). Greener Journal of Agricultural Sciences, 5(4), 110-117.

Ahmadian, A. (2015). The Impact of Oil Price Fluctuations on the Automobile Industry. OPEC Energy Review, 8(2), 141-161.

Ahmed, A. E. A. (2018). Relationship between Crude Oil Price Fluctuations and Inflation in Oman (1990-2017). GCNU Journal, 12, 1-46.

Applanaidu, S. D. A., Arshad, F. M., Shamsudin, M. N., \& Hameed, A. A. A. (2011). An Econometric Analysis of the Link between Biodiesel Demand and Malaysian Palm Oil Market. International Journal of Business and Management, 6(2). 35-45.

Arasim, D. H., \& Karia, A. A. (2015). Identifying and Forecasting the Factors that Derive CPO Prices in Malaysia Using NARX Model. International Journal of Case Studies, 4(12), 4-14.

Aziz, M. I. A., \& Applanaidu, S. D. A. (2017). Effects of Palm Oil Price on Exchange Rate : A Case Study of Malaysia and Indonesia. Institutions and Economies, 9(4), 71-87.

Bentivoglio, D., Finco, A., \& Bucci, G. (2018). Factors Affecting the Indonesian Palm Oil Market in Food and Fuel Industry: Evidence from A Time Series Analysis. International Journal of Energy Economics and Policy, 8(5), 49-57.

Cheng, D., Shi, X., Yu, J., \& Zhang, D. (2019). How Does the Chinese Economy React to Uncertainty in International Crude Oil Prices? International Review of Economics and Finance, 64, 147-164.

Chuangchid, K., Wiboonpongse, A., Sriboonchitta, S., \& Chaiboonsri, C. (2012). Factors Affecting Palm Oil Price Based on Extremes Value Approach. International Journal of Marketing Studies, 4(6), 54-65.

Department of Statistics. (2017). Selected agricultural indicators, Malaysia, 2017. https://www.dosm.gov. 
INTERNATIONAL JOURNAL OF ACADEMIC RESEARCH IN BUSINESS AND SOCIAL SCIENCES

Vol. 10, No. 5, May, 2020, E-ISSN: 2222-6990 @ 2020 HRMARS

my/v1/index.php?r=column/cthemeByCat\&cat=72\&bul_id=MDNYUitINmRKcENRY2FvMmR5 T WdGdz09\&menu_id=ZOVTZGU1UHBUT1VJMFIpaXRRR0xpdz09. Accessed April 8, 2020.

Mahdi, A. E.-S. A. A. (2012). The Impact of Crude Oil Price Changes on Money Supply (M2) In Oman (1990-2016). 5(June), 259-278.

Malaysian Palm Oil Board. (2017). Malaysian oil palm industry performance 2016 and prospects for 2017.

http://www.mpob.gov.my/images/stories/pdf/2017/2017_Dr.KushairiPALMEROS2017.pdfA ccessed on April 8, 2020.

Mukhriz, I. A. A., \& Applanaidu, S. D. (2017). Effect of Palm Oil Price on Exchange Rate: A Case Study of Malaysia and Indonesia. Institutions and Economies, 9(4), 71-87.

Norlin, K., Hakimah, N. A. H., Sharmila, T., \& Nur, F. M. (2018). Crude Palm Oil Price Forecasting in Malaysia: An Econometric Approach. Jurnal Ekonomi Malaysia, 52(3), 247-259.

Punati, N., \& Raju, R. (2017). Determinants of Crude Oil Prices in India. SSRG International Journal of Economics and Management Studies, 4(10), 1-9.

Rahman, N. M. N. A. (2013). The Empirical Analysis on Prices of the Malaysian Crude Palm oil Futures Market. International Review of Management and Business Research, 2(2), 401-412.

Rifin, A. (2010). The Effect of Export Tax on Indonesia's Crude Palm Oil (CPO) Export Competitiveness. ASEAN Economic Bulletin, 27(2), 173.

Shariff, F., Rahman, A. K. A., \& Amirudin, M. N. (2006). The Elasticity of Foreign Demand for Malaysian Palm Oil. Oil Palm Industry Economic Journal, 6, 1-6.

Soundarapandiyan, K., \& Ganesh, M. (2017). An Analytical View of Crude Oil Prices and Its Impact on Indian Economy. IOSR Journal of Business and Management, 23-28.

Susila, W. R. (2004). Contribution of Oil Palm Industry to Economic Growth and Poverty Alleviation in Indonesia. Jurnal Litbang Pertanian, 23(1), 107-114.

Tang, K. H. D. (2018). Climate change in Malaysia: Trends, contributors, impacts, migration and adaptations. Science of the Total Environment, 650(2), 1858-1871.

Tang, K. H. D., \& Al Qahtani, H. M. S. (2019). Sustainability of oil palm plantations in Malaysia. Environmental Development and Sustainability. https://doi.org/10.1007/s10668019-00458-6

Zabid, M. F. M., \& Abidin, N. Z. (2015). Palm Oil Industry: A Review of the Literature on the Modelling Approaches and Potential Solution. AIP Conference Proceedings.

Zakaria, K., Salleh, M. K., \& Balu, N. (2017). Factors Affecting Palm Oil Demand in India. Oil Palm Industry Economic Journal, 17(2), 25-33. 